\title{
The Impacts of Socio-Economic Factors on The Income of Salak Nglumut (Salacca Zalacca Sp.) Farmers in Srumbung District of Magelang Regency
}

\author{
Tutik Nurul H \\ Agribusiness Department, \\ Faculty of Agriculture \\ Sebelas Maret University \\ Surakarta, Indonesia \\ tuetik3@gmail.com
}

\author{
Heru Irianto \\ Agribusiness Department, \\ Faculty of Agriculture \\ Sebelas Maret University \\ Surakarta, Indonesia \\ irian_her@yahoo.com
}

\author{
R.R. Aulia Qonita \\ Agribusiness Department, \\ Faculty of Agriculture \\ Sebelas Maret University \\ Surakarta, Indonesia \\ auliaqonita@yahoo.co.id
}

\begin{abstract}
The purpose of this study were to determine (1) the income of Salak Nglumut (Salacca Zalacca) farmers, (2) the impact of capital on income, (3) the impact of age on the correlation betwen capital and income; (4) the impact of land area on income, (5) the impact of age on the correlation between land area and income, (6) the impact of the number of family dependents on income (7) and the impact of age on the correlation between the number of family dependents and income. The method used was survey method with tiered regression analysis on a sample of $\mathbf{4 0}$ Salak $\mathbf{~ g l u m u t}$ farmers. The results conclude that (1) the average income of Salak Nglumut farmers in Srumbung District is Rp. 1,075,392.25; (2) capital has a negative effect on income; (3) age moderates the relationship of capital to income; (4) land area has a positive impact on income; (5) age moderates the correlation between land area and income; (6) number of family dependents does not have impact on income and (7) age does not moderate the correlation between the number of family dependents and income. Based on the findings, the following suggestion are proposed: 1) Optimizing Salak Nglumut cultivation by implementing production factors according to the recommended standard operating procedures for cultivation; 2) minimizing the influence of the correlation between age and land area on income, it is necessary to educate young farmers to obtain a high level of income; 3). improving the skills of young farmers through various technical training for Salacca Zalacca cultivation.
\end{abstract}

Keywords- Age, Income, Land Area, Model, Moderating Variable

\section{INTRODUCTION}

The agricultural sector is an important sector in the national economic development. One of the agricultural subsectors is horticultural crops. Horticultural commodities are potential commodities that have high economic value and the potential to be continously developed. Many Indonesian native fruit cultivation efforts have been developed today as an alternative to utilize land optimally [1]. One of the alternatives is cultivating zalacca horticulture crops because the market demand for zalacca fruit is quite high, including the demand for Salak Nglumut (Salacca Zalacca Sp. Specially Cultivated in Nglumut Village).

According to data from [2], the demand for Salak Nglumut in Indonesian society from 2015 to 2016 had increased by 4.24 percent. Indonesian zalacca exports in 2015 recorded a volume of $758,656.03 \mathrm{~kg}$, and in 2016 amounted to $790,888.05 \mathrm{~kg}$. The National Socio-economic survey data
(2017) also showed that zalacca consumption had increased in 2015 and 2016, from 331.20 million to 436.93 million. The demand for Salak Nglumut continues to increase along with its popularity and the national population growth.

Magelang is one of the areas in Central Java that develops horticultural commodities. Magelang District has superior varieties of Zalacca which was released by the Minister of Agriculture Syarifuddin Baharsjah in 1993, namely Salak Nglumut originating from Nglumut Village, Srumbung District, Magelang Regency. Salak Nglumut becomes a featured commodity due to its high growth capability, good quality, and high economic value. According to [3] salak nglumut is originating from Magelang. It has similar characteristics with salak pondoh super (super salacca zalacca sp). Salak pondoh is widely grown by farmers in Sleman. Good management of Salak Nglumut farming is required so that farmers' income can be increased. The potential characteristics of zalacca production provide opportunities for farmers to earn a decent income for the farmer families.

Farmers' characteristics are displayed through their mindset, attitude patterns and action patterns towards the environment. Different characteristics will result in different actions. This also applies for the matter of generating income from their farms. According to [4], factors that influence income can be in the forms of land area, labor, capital, production level, and production facilities. In addition, there are socio-economic factors such as farmer's age, number of family dependents and other factors that affect the income level. Different from Soekartawi's opinion, [5] and [6] found direct influence of age on income dependent variables. Thus, in this study, the impact of age on income dependent variables is moderating the impact of independent variables on dependent variables (see [7], [8]).

Based on the description above, the problems can be formulated as follow: 1) How much is the farmers' income from their Salak Nglumut farming in Srumbung District. 2) Does capital have impact on Salak Nglumut farmers' income in Srumbung District. 3) Does age moderate capital impact on the income of Salak Nglumut farmers in Srumbung District. 4) Does the land area have impact on Salak Nglumut farmers' income in Srumbung District. 5) Does age moderate the land area impact on Salak Nglumut farmers' income in Srumbung 
District. 6) Does the number of family dependents have impact Salak Nglumut farmers' income in Srumbung District 7) Does the age moderate the impact of family dependent number on Salak Nglumut farmers' income in Srumbung District.

\section{METHODS}

\section{A. Basic Research Method}

The basic research method used in this research was descriptive analysis method. [9] described descriptive research as a research that describes and explains in details regarding to symptoms or objects under study. Descriptive research was conducted to determine the values of independent variables, either one or more than one variable without comparing or connecting to other variables. The data obtained from the population sample were then analyzed by statistical method. The data collection technique employed in this research was survey method, by taking samples from a relatively large population and uses a questionnaire as the main instrument ( [10]

\section{B. Research Location Determination Method}

The chosen research location was Srumbung District of Magelang Regency. This determination was based on the fact that Srumbung District is the highest Salacca zalacca producing district and is the center of Salak Nglumut cultivation where this commodity has become a featured variety in Magelang Regency. The chosen locations were Kaliurang Village with Ngudi Luhur farmer group and Ngargosoko Village with farmer group that was named according to the village name; Ngargosoko farmer group. Kaliurang Village and Ngargosoko Village were chosen as research sites because salak nglumut is the main commodity in both villages and those villages have better marketing system compared to other villages.

\section{Sampling Method}

The samples were determined using proportional random sampling method. Samples were taken from each of the selected villages using proportional method. This was done so that the number of samples from each village was directly proportional to the total population of salak ngumut farmers in the two villages. Furthermore, the number of analyzed samples in this study was set at 40 farmers to meet the normal distribution requirements. Based on these two considerations, the total samples of Salak Ngumut farmers were 23 farmers from Kaliurang Village and 17 farmers from Ngargsoko Village.

\section{Data Analysis Method}

\section{a) Income Analysis of Salak Ngumut Farming}

Income $(\mathrm{Pd})$ is the difference between total revenue (TR) and total costs (TC) with the concept of operational cost of income [11]. The amount of Salak Nglumut farming income in one planting season was calculated by the following formula:

\section{Information :}

$$
\mathrm{Pd}=\mathrm{TR}-\mathrm{TC}
$$

$\mathrm{Pd}=$ Income of Salak Nglumut farming business (Rp/Ha/month)

$\mathrm{TR}=$ Total Revenue of Salak Nglumut farming business ( $\mathrm{Rp} / \mathrm{Ha} / \mathrm{month})$
$\mathrm{TC}=$ Total Cost of Salak Nglumut farming business (Rp/Ha/month)

\section{a) Tiered Multiple Linear Regression Analyisis}

The data analysis method used was a multiple 2tiered linear regression analysis to test the main impacts which was the correlation between independent variables and exogenous variables, as well as to test the interaction effect of independent variables and exogenous variables on the dependent variable [12]. 2-tiered regression equations were formulated as follows:

Tier 1: $Y=a+b_{1} X_{1}+b_{2} X_{2}+b_{3} X_{3}+b_{4} X_{4}+e_{i} \ldots \ldots \ldots .(1)$

Tier 2: $Y=a+b_{1} X_{1}+b_{2} X_{2}+b_{3} X_{3}+b_{4} X_{4}+b_{5} X_{1} * X_{4}+$ $\mathrm{b}_{6} \mathrm{X}_{2} * \mathrm{X}_{4}+\mathrm{b}_{7} \mathrm{X}_{3} * \mathrm{X}_{4}+\mathrm{e}_{\mathrm{i} . . .(2)}$

Information:

$\mathrm{Y} \quad$ income

A : constant

$\mathrm{b}_{1}+\mathrm{b}_{7} \quad$ : regression coefficient

X1 : capital

$\mathrm{X} 2 \quad$ : land area

X3 : number of family dependent

$\mathrm{X} 4 \quad:$ age

$\mathrm{X}_{1} * \mathrm{X}_{4} \quad$ : interaction between capital and age

$\mathrm{X}_{2} * \mathrm{X}_{4} \quad$ : interaction between land area and age

$\mathrm{X}_{3} * \mathrm{X}_{4} \quad:$ interaction between number of family dependent and age

$\mathrm{e}_{\mathrm{i}} \quad$ : error

The test was conducted using SPSS software in the form of determination coefficient test, $F$ test, and $t$ test for the first tier. For the second tier of regression, in addition to the determination of coefficient test, $F$ test and $t$ test, to find out the difference in delta $\mathrm{R}^{2}, \mathrm{~F}$ delta test was conducted on $\mathrm{R}^{2}$ before the $t$ test. According to [13], the formula for calculating the $\mathrm{F}$ delta $\mathrm{R}^{2}$ test is as follows:

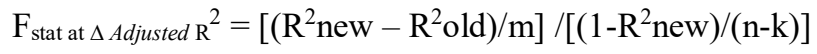

Information:

$\mathrm{R}^{2}$ new : $\mathrm{R}^{2}$ value from the new regression equation

$\mathrm{R}^{2}$ old : $\mathrm{R}^{2}$ value from the old regression equation

$\mathrm{m} \quad$ : Number of new varable

$\mathrm{N} \quad$ : Number of data

$\mathrm{K} \quad$ : Number of parameters from the new equation

Classical Assumption Analysis.

To test the validity of the formulated regression model to be applied, the conditions that must be met were the autocorrelation test and multicolinearity test.

\section{RESULTS AND DISCUSSION}

\section{Results Respondents' Characteristics}

Salak Nglumut farmers who became the respondents are male farmers. The selected respondents are heads of households who are also the main actors in salak nglumut farming business despite the undeniable that the farming business also involves the female farmers' decisions. Male respondents dominate the sample because they spend more time doing activities in the farm than female respondents. The educational background of the respondents were $0.25 \%$ at 
junior high school level, 48\% (most of the respondents) at high school level, $7 \%$ at academy/higher education, and the remaining $20 \%$ at elementary school level. The lenght of the respondents' work period ranged from 4 - 30 years, which amounted to $55 \%$ of the respondents. In general, most of the respondents in this study work as farmers as their livelihood, amounting to 37 people with a percentage of $92.5 \%$, and the rests work as village officials. The majority of family dependents were 4 people $(62.5 \%)$, more than 4 people $(20 \%)$, and less than 4 people (17.5\%). These conditions indicate that most respondents implement family planning programs. This means that salacca zalacca farmers in Srumbung district have paid enough attention to the welfare of their families. This was also indicated by the average age of the family head (respondents) were around 35 years, so that they are still in productive age and relatively young. Discussion should be consistent and should interpret the results clearly and concisely, address logically mechanism and explanation, supported with suitable literatures. The discussion should show relevance between the results and the field of investigation and/or hypotheses.

\section{A. Income of Salak Nglumut Farmers}

According to [14] income is the result of acquisition derived from the costs of production factors or productive services. This definition shows that income is all acquisitions derived from the cost of production factors and the total output spent for production within a certain period. Income is the result of reducing revenues with the total cost of farming business. Revenue is the result of the total production multiplied by the product price, while the total cost is the operational cost consisting of the costs for production facility purchases, wages of outsource workers and families, other costs, and the depreciation costs of equipment set aside by farmers for their farming activities[12]. The average income of Salak Nglumut farming was Rp. 1,075,392.25 for each month derived from the total revenue minus the total costs of farming business. The Income Table is presented as follows:

Table 1. Income of Salak Nglumut Farmers

\begin{tabular}{llr}
\hline No & Description & Monthly Calculation \\
\hline 1. & $\begin{array}{l}\text { Operational } \\
\text { Rp/ha/month }\end{array}$ & Cost \\
2. & $\begin{array}{l}\text { Revenue } \\
\text { Rp/ha/month }\end{array}$ & Rp. $3.418 .8364,25$ \\
3. & $\begin{array}{l}\text { Income } \\
\text { Rp/ha/month }\end{array}$ & Rp. $1.075 .392,25$ \\
\hline
\end{tabular}

Sumber: Primary Data Analysis

\section{B. Socio-economic Factors Affecting Farmers' Income}

Based on the description of socio-economic factors that have impact on income, the formulated problems were (1) the impact of capital on income; (2) the impact of age on the correlation between capital and income; (3) the impact of land area on income; (4) the impact of age on the correlation between land area and income; (5) the impact of family dependent number on income; and (6) the impacts of age on the relationship between the number of family dependents and income. Based on these problems, the results of 2-tiered regression equation model analyses are presented in table 2 as follows:
First Tier, the test results on tier 1 regression model showed good goodness-of-fit (test $F=17.414, p<0.001$ ). This showed that the regression model could be used to explain the impact of socio-economic factors on income. Adjusted $\mathrm{R}^{2}$ results of 0.627 , which means $62.7 \%$ of the income variable can be explained by the variables of capital, land area, and number of family dependents and age, while the remaining $37.3 \%$ was explained by other causes.

Table 2. Results of Tiered Regression Analysis with Dependent Variable of Income

\begin{tabular}{|c|c|c|}
\hline $\begin{array}{l}\text { Independent } \\
\text { Variable }\end{array}$ & Tier 1 & Tier 2 \\
\hline Constant & $\begin{array}{c}249983.378 \\
(0.537)\end{array}$ & $\begin{array}{c}-218646.610 \\
(-0.146)\end{array}$ \\
\hline \multicolumn{3}{|l|}{ Main Impacts } \\
\hline Capital & $\begin{array}{c}0.218 \\
(1.253)\end{array}$ & $\begin{array}{c}-1.478 \\
(-3.057)^{* * *}\end{array}$ \\
\hline Land area & $\begin{array}{c}0,627 \\
(3.522)^{* * *}\end{array}$ & $\begin{array}{c}2.091 \\
(4.414)^{* * *}\end{array}$ \\
\hline$\sum$ Family dependent & $\begin{array}{c}-0.061 \\
(-0.595)\end{array}$ & $\begin{array}{c}-0.006 \\
(-0.016)\end{array}$ \\
\hline Age & $\begin{array}{c}-0.027 \\
(-0.255)\end{array}$ & $\begin{array}{c}0.187 \\
(0.451) \\
\end{array}$ \\
\hline \multicolumn{3}{|c|}{ Two way interaction impacts } \\
\hline Age*Capital & & $\begin{array}{c}2.151 \\
(3.739)^{* * *}\end{array}$ \\
\hline Age*Land area & & $\begin{array}{c}-2.032 \\
(-3.295)^{* * *}\end{array}$ \\
\hline \multirow{2}{*}{$\begin{array}{l}\text { Age* }{ }^{*} \text { Family } \\
\text { Dependent }\end{array}$} & & -0.117 \\
\hline & & $(-0.206)$ \\
\hline F-test & $17.414 * * *$ & $15.232 * * *$ \\
\hline R-squared $\left(\mathrm{R}^{2}\right)$ & 0.666 & 0.769 \\
\hline Adjusted $\mathrm{R}^{2}$ & 0.627 & 0.719 \\
\hline$\Delta \mathrm{R}^{2}$ & & 0.092 \\
\hline F-test at $\Delta \mathrm{R}^{2}$ & & $1.625^{*}$ \\
\hline
\end{tabular}

Second Tier, the test results on tier 2

Model also showed good goodness-of-fit ( $F$ test $=15,232, p$ $<0,001)$. This means that the independent variables simultaneously influence income. Adjusted $\mathrm{R}^{2}$ value was 0.719 which means that $71.9 \%$ of income variable could be explained by the variables of capital, land area, and the number of family dependents, age, interaction of age with capital, interaction of land area with age, and interaction of family dependent number with age. The remaining $28.1 \%$ was explained by other factors that were not examined in this study.

Furthermore, the hypothesized two-way interaction impact contributed to the increased goodness of fit tested (Test $\mathrm{F}$ at $\left.\Delta \mathrm{R}^{2}=1.625, p<0.05\right)$. This indicated that the tier 2 model differed significantly from the tier 1 model to explain the variables of capital, land area, and number of family dependents, interaction of age in the correlation of capital on income, interaction of age in the correlation of land area on income, and interaction of age in the correlation of family 
dependent number on income. The significant value of the $\mathrm{F}$ test at both tiers showed that the age variable played a role to strengthen or weaken the correlation of the independent variables to the dependent variable.

The discussion of the hypothesis testing results of the regression results can be described as follows:

\section{The Impact of Capital (X1) on Income}

Test results in tier 1 indicated positive impact of capital variable on income $(\beta=0.218 ; \mathrm{Z}$ value $=1.253, \mathrm{p}>0.1)$, while the test results in tier 2 indicated negative correlation pattern $(\beta=-1.478 ; Z$ value $=-3,057, p<0.01)$. These results indicated that the capital variable at tier 1 and 2 showed the inconsistency of capital impact on income so that hypothesis 1 was rejected. This means that higher capital would actually cause a decrease in income. These results indicated that the average use of capital by salak nglumut farmers in Srumbung district was already above the ideal use of capital that should be invested in the farm. The capital was used for the procurement of fertilizers, pesticides and other production facilities. The impact of capital that decreased income indicated that the procurement of fertilizers, pesticides and other production facilities was already excessive.

\section{The Impact of Land Area (X2) on Income}

The test results in tier 1 indicated positive impact of land area variable on income $(\beta=0.627 ; Z$ value $=3.522, p<0.01)$. While the test results on tier $2(\beta=2.091 ; Z$ value $=4.414, p$ $<0.01)$ indicated that the land area variable in tier 1 and 2 showed consistency of land area impact on income, so that the results supported and answered the hypothesis (H2). This result is in line with the opinion of [4], and the results of [5]); and [6]. This means that the higher the land area owned and the better the quality of land, the higher the income of the farmers. Broader land owned will provide an opportunity to have a large production by working on the same commodity.

3. The impact of Dependent Family Number (X3) on income

The test results in tier 1 for the variable of family dependent number indicated a negative correlation patterns that were not significant $(\beta=-0.061$; $\mathrm{Z}$ value $=-0.095, \mathrm{p}>0.10)$, as well as tier the 2 test results $(\beta=-0.006$; value $Z=-0.016, p>0.10)$. Thus the variable of family dependent number does not have a significant impact on the income of Salak Nglumut farmers in Srumbung District. This is because in their daily lives, the farmers still have the opportunity to cultivate other commodities such as chili, corn, and long beans. In addition, some farmers still have other jobs outside of farming.

4. The Impact of Interaction of Age with Capital Variable on Income

The results of multiple regression tests by calculating the interaction of age variable with capital variable significantly moderated the impact of capital on income. The hypothesis which stated that older age strengthened the influence of capital on income $(\mathrm{H} 4)$ was supported in tier 2 testing $(\beta=2.151 ; Z$ value $=3.739, p$
$<0.01)$. This means that the older the age of the farmer, the stronger the impact of capital on income. This also means that the increasing age of farmers will be followed by stronger impact of capital on income. This result must be observed carefully because at this stage, the condition of capital has a negative impact, thus an increase in age means a faster decline in income.

5. The Impact of Interaction of Age and land area variables on Income

The hypothesis which stated that older age strengthens the impact of land area on income (H5) was supported by tier 2 test results $(\beta=-2.032 ; Z$ value $=$ $(3.295, \mathrm{p}<0.01)$. This means that the older the age, the weaker the impact of land area on income, as for older farmer, the land area would be less productive so that the management of the land would be reduced, which in turn would result in a lack of income obtained. The respondents' age, with an average of 35 years, certainly became a weakness in the farming business, in which with older age, physical abilities will tend to decrease even though on the other hand the farming experience is increasing.

6. The Impact of Interaction of Age Variable with The number or Family Dependents on Income

The results of multiple regressions by calculating the interaction of age variables with number of family dependent variable did not moderate the impact of family dependent number on income. This is indicated by the results of tier 2 testing $(\beta=-0.117 ; Z=$ $-0.206, p>0.10)$. This result indicated that the age variable did not have a role in the impact of family dependent number on income.

\section{Information of Proofreading}

Jotika Purnama Yuda. Service and Language Development Unit of Sebelas Maret University

\section{CONCLUSION}

Conclusion should be written briefly, answer the aims or hypothesis

According to the research and discussion results, the following conclusions are drawn: (1) the average income of Salak Nglumut farmers in Srumbung District is Rp. $1,075,392.25$; (2) capital has a negative effect on income; (3) age moderates the relationship of capital to income; (4) land area has a positive impact on income; (5) age moderates the correlation between land area and income; (6) number of family dependents does not affect income and (7) age does not moderate the correlation between the number of family dependents and income. Based on the findings, the following suggestion are proposed: 1) Optimizing Salak Nglumut cultivation by using production factors according to the recommended standard operating procedures for cultivation, 2) minimizing the influence of the correlation between age and land area on income, it is necessary to educate young farmers to obtain a high level of income; 3) improving the skills of young farmers through various technical training in Salacca Zalacca cultivation. 


\section{REFERENCES}

[1] Anarsis, W. Agribisnis Komoditas Salak. PT. Aksara. Jakarta. 2006

[2] BPS. Statistik Tanaman Buah-buahan dan Sayuran Tahunan Indonesia. Jakarta. 2017

[3] Nandariyah. Salak: Kajian Budidaya dan Kultur Jaringan. UNS Press. Solo. 2011

[4] Soekartawi. Analisis Usaha Tani. UI Press. Jakarta. 1995

[5] Thamrin, M., Surna, H. dan Fahrul, H. Pengaruh Faktor Sosial Ekonomi Terhadap Pendapatan Petani Pinang. Jurnal Agrium. Vol. 17 No. 2. 2012

[6] Rangkuti, K., Sasmita, S. Muhammad, T. dan Rui, A. Pengaruh Faktor Sosial Ekonomi terhadap Pendapatan Petani Jagung. Jurnal Agrium Volume 19 No. 1. 2014.

[7] Hermawan, H dan Sulasmi. Peranan Faktor Usia dalam Memoderasi Pengaruh Pemberian Insetif terhadap Motivasi Kerja Karyawan Kantor Direksi PT. PG Rajawali Surabaya. Jurnal Manajemen Teori dan Terapan Tahun 7. No.2, Agustus 2014. 2014.

[8] Pratama, MP. Pengaruh Usia, Status Sosial Ekonomi, Kompetensi dan Supervisi Terhadap Kreativitas dengan Need for Achievment sebagai Variabel Pemoderasi. Jurnal Ekonomi Vol. 6 No. 1 Januari - Juni 2017, ISSN: 2302-7169. 2017.

[9] Sugiono. Metode Penelitian Pendidikan (Pendekatan Kuantitatif, Kualitatif, dan R\&D). Alfabeta. Bandung. 2011.

[10] Singarimbun, $M$ dan Effendi. Metode Penelitian Survey. PT. Pustaka LP3ES. Jakarta. 1995.

[11] Suratiyah, K. Ilmu usahatani Edisi Revisi. Penebar Swadaya. Jakarta. 2015.

[12] Grau, R., Salanova, M., and Peiro, J. Moderator Effects Of SelfEfficacy On Occupational Stress, Psychology in Spain, Vol. 5. No 1. 63-74. 2001.

[13] Hartmann, F., G. H. and Moers, F. Testing contingency hypotheses in budgetary research using moderated regression analysis: a second look, Accounting, Organizations and Society, Vol. 28. 2003.

[14] Sadono, Sukirno. Ekonomi Pembangunan Proses Masalah dan Dasar Kebijakan. Kencana. Jakarta. 2006. 